\title{
Implementation Of The C4.5 Algorithm For Recruitment Of E-Sports Team Members
}

\author{
Akhmad Efendi ${ }^{* 1}$, Anggit Dwi Hartanto ${ }^{2}$ \\ ${ }^{1}$ Informatika Universitas AMIKOM Yogyakarta, ${ }^{2}$ Fakultas Ilmu Komputer Universitas AMIKOM \\ Yogyakarta \\ Email : ${ }^{* 1}$ akhmad.efendi@ students.amikom.ac.id, ${ }^{2}$ anggit@amikom.ac.id
}

\begin{abstract}
Fenomena E-Sport in an increasingly fast-paced world, creating a global culture ranging from international E-Sport tournaments to the birth of management that houses the competing ESport teams to be the best. E-Sport teams need players or gamers who have high skills, but it is not only the skill level of a player that determines the success of an E-Sport team in a tournament, there are other factors that determine the success of an E-Sport team, where factors this can be used in determining the decision to recruit players or gamers to become members of the E-Sport team. Decision support systems (DSS) is one of the systems that can be relied upon as a method to assist an organization or E-sports team management in assisting the decision-making process. One method that can be used in DSS is to use the Decision Tree C4.5 Algorithm. The solution technique is to use entropy and information gain for the expansion of decision trees. C4.5 algorithm is a decision tree-based method. In the C4.5 algorithm, the selection of attributes is done using Gain, Ratio, by finding the Entropy value. C4.5 algorithm can provide effective results in supporting a decision.
\end{abstract}

Keyword - E-Sport, DSS, Decision Tree, C4.5 algorithm

\section{INTRODUCTION}

The need to improve a resource and the quality of performance is a challenge that is often faced by an E-Sports team, and one that affects the efforts of the team to answer that challenge is when recruiting Team members. Many E-Sports teams have the process of recruiting prospective members in a conventional manner. By relying on the visible side, it is possible for the decision makers not to be right in recruiting members according to the team criteria needed. Even though the quality of each team member is a key factor in achieving the best performance of a team.

E-Sports is a unique phenomenon among people, especially young people. The current ESports phenomenon is so fast that it is astonishing to several parties, both investors, media, government, and society in general. With the E-Sports phenomenon in an increasingly fast world, a global culture has been created, starting from international E-Sports tournaments, to the birth of ESports Teams that compete with each other to be the best, both on a national or international scale.

The creation of competition between E-Sports Teams in the world requires E-Sports teams to have strong and tough team qualities where the members are clearly required to have high skills and competencies to show their best performance and abilities in every tournament.

Currently, in the agency of an E-Sports Team, most of the recruitment process or entry of ESport players or members is still based on just 'seeing' the player's skill level, even though increasing the success of an E-Sports team can be influenced by many factors. , not only depending on the skill level the player has. Other factors that can increase the success of an E-Sports team provide an opportunity, the recruitment process of this E-Sports team member should be carried out in a more logical and systematic way.

Creating opportunities in the member recruitment process can be facilitated by establishing a decision support system. Much research has been done to solve this problem using various algorithms. One of them is by using the $\mathrm{C} 4.5$ decision tree algorithm.

Based on the foregoing, the writer wants to design a recruitment system for E-Sports team members which is expected to help E-Sports agencies in making decisions to determine whether or not a prospective member of an E-Sports team is worthy. 


\section{RESEARCH METHODS}

The research method used in the application of the $\mathrm{C} 4.5$ algorithm for recruiting members of the E-sport Team, uses a research design aimed at the following Figure:

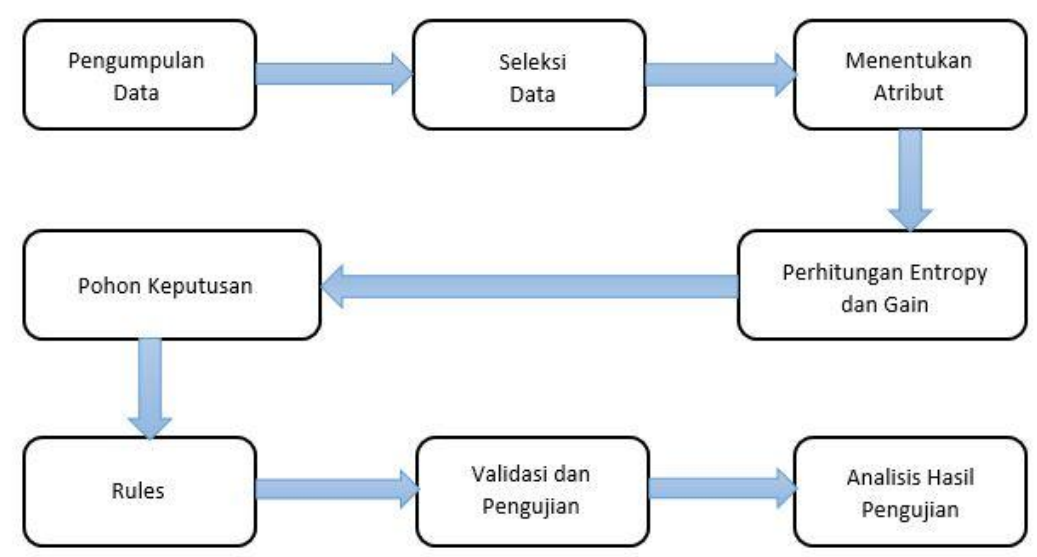

Figure 1. Research Design

\section{A. Data Collection}

Data collection is the stage of collecting data that will be used in the C4.5 classification algorithm process.

\section{B. Variable Determination}

\subsection{Player Experience}

This attribute describes the motivation of the prospective member in playing the game and also shows the environment in which the prospective member comes from playing the game. Where there are two categories, namely "Professional" and "Hobby". "Professional" means he is from a professional group who has participated in a tournament before, while "Hobbies" means he comes from a group that has never joined any team but has the maximum effort and opportunity to become a member of the E-Sports team.

\subsection{Skill}

Experience determines skills, the more experience playing games, the better skills one has. This attribute is divided into two categories based on predetermined values, these values are:

- A value of $\geq 70$ means that you have a skill that meets the requirements.

- A value $<70$ means you have a skill that is not maximal and does not meet the requirements.

\subsection{Psychological Value}

This psychological test is to determine the mental health of prospective team members, in this psychological test it can be assessed how the prospective member controls emotions, etc. This attribute contains the results of an applicant's psychological test. The applicant's psychological score contains a score between 0-9, divided into 2 classes, namely 0-4 and 5-9.

\subsection{The Value Of Intelligence}

This variable determines the level of intelligence of a player, which can be used to see how prospective members make decisions. Intelligence values are also grouped into two categories, namely:

- A value of $\geq 70$ means that it has an intelligence value that meets the requirements.

- A value $<70$ means that the intelligence value does not meet the requirements. 


\section{Data Selection}

Data selection, namely the stage of selecting data to be used in the $\mathrm{C} 4.5$ classification algorithm process.

\section{Data Transformation}

Data transformation is the process of converting data into an appropriate form, so that it can be processed with the $\mathrm{C} 4.5$ algorithm calculation.

\section{E. Calculation Of Entropy and Information Gain}

To calculate gain, the formula is used:

$\operatorname{Gain}(S, A)=\operatorname{Entropy}(S)-\sum_{i=1}^{n} \frac{S i}{S} \times \operatorname{Entropy}(S i)$

Information :

S : Case Collections

A : Attribute

n : Number of Attribute Partitions A

$\mathrm{Si} \quad$ : Number of Cases in Partition i

$\mathrm{S} \quad$ : Number of Cases in $\mathrm{S}$.

To calculate Entropy, the formula is used:

$$
\operatorname{Entropy}(S)=\sum_{i=1}^{n}-p i \times \log _{2} p i
$$

Information :

S : Case Collections

A : Features

n $\quad$ : The number of partitions $S$

pi : The proportion of Si to $S$

\section{F. Decision Tree}

The decision tree is the result of the entropy and information gain calculation process, after repeated calculations until all the tree attributes have a class and the calculation process can no longer be carried out.

\section{G. Model Rules}

The rules / Rule model is an explanation that shows a description of the logical rules resulting from the decision tree obtained

\section{H. Validation and Testing}

Validation and testing are tests carried out to find out all functions are working properly or not.

\section{RESULTS AND DISCUSSION}

In designing a decision tree using the $\mathrm{C} 4.5$ algorithm, it is necessary to create Target Attribute Data. The Attribute Data Table as shown in Table 1. 
Table 1. Target Attribute Data

Target Attribute

Description

Yes

Applicants Pass

No

Applicants Did Not Pass

Furthermore, the Target Attribute Data will be used to analyze the data set existing based on predetermined variables

Table 2. Data Set Analysis

\begin{tabular}{|c|c|c|c|c|}
\hline Atribut & Nilai & Jumlah Kasus & Ya & Tidak \\
\hline \multirow{2}{*}{ Pengalaman Pemain } & $\begin{array}{c}\text { Pofesional } \\
\text { Hoby }\end{array}$ & 17 & 0 & 17 \\
\cline { 3 - 5 } & $\begin{array}{c}\geq 70 \\
\text { Skill }\end{array}$ & 83 & 25 & 58 \\
\cline { 3 - 5 } & $<70$ & 70 & 10 & 60 \\
\hline \multirow{2}{*}{ Psikotes } & $0-4$ & 30 & 15 & 15 \\
\cline { 3 - 5 } & $5-9$ & 31 & 0 & 61 \\
\hline \multirow{2}{*}{ Intellegensi } & $\geq 70$ & 43 & 19 & 20 \\
\cline { 3 - 5 } & $<70$ & 57 & 6 & 51 \\
\hline
\end{tabular}

This C4.5 algorithm uses the entropy and gain values of each attribute in determining the root and decision tree nodes.

The first step in finding entropy and variable gain is calculating the total entropy from the data set.

Table 3. Node 1 Calculation

\begin{tabular}{|c|c|c|c|c|c|c|c|}
\hline Node & Atribut & Nilai & $\begin{array}{c}\text { Jumlah } \\
\text { Kasus }\end{array}$ & Lulus & $\begin{array}{l}\text { Tidak } \\
\text { Lulus }\end{array}$ & Entropy & Gain \\
\hline \multirow{9}{*}{1} & Total & & 100 & 25 & 75 & 2 & \\
\hline & \multirow{2}{*}{ Skill } & $\geq 70$ & 83 & 25 & 58 & 1.731181183242 & \multirow{2}{*}{0.563117909} \\
\hline & & $<70$ & 17 & 0 & 17 & 0 & \\
\hline & \multirow[b]{2}{*}{ Psikotes } & $0-4$ & 10 & 0 & 10 & 0 & \multirow[b]{2}{*}{0.336802784} \\
\hline & & $5-9$ & 90 & 25 & 65 & 1.847996907 & \\
\hline & \multirow{2}{*}{$\begin{array}{c}\text { Pengalaman } \\
\text { Pemain }\end{array}$} & Pofesional & 30 & 15 & 15 & 1 & \multirow{2}{*}{-0.265148445} \\
\hline & & Hoby & 70 & 10 & 60 & 2.807354922 & \\
\hline & \multirow{2}{*}{ Intellegensi } & $\geq 70$ & 43 & 19 & 24 & 1.178337241 & \multirow{2}{*}{-0.358003696} \\
\hline & & $<70$ & 57 & 6 & 51 & 3.247927513 & \\
\hline
\end{tabular}

From the table above, it can be seen that Skill is the attribute with the highest gain value, namely 0.563117909 . Skills are placed as the root tree. 


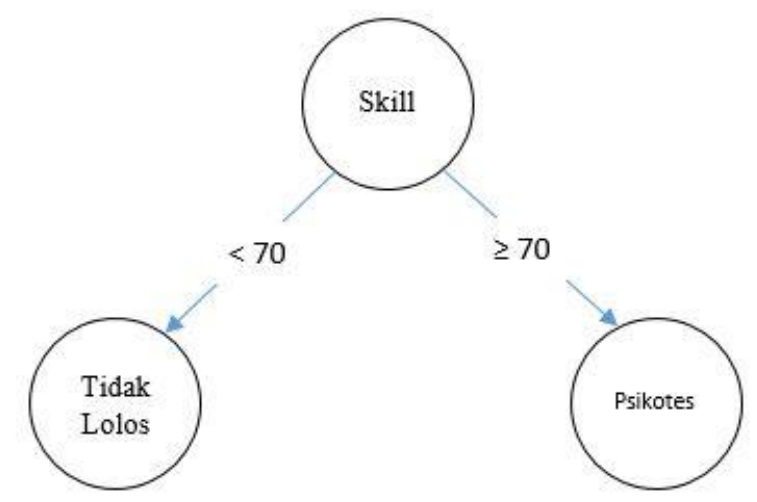

Figure 2. Decision Tree calculation result of node 1

Table 4. Node Calculation 1.1

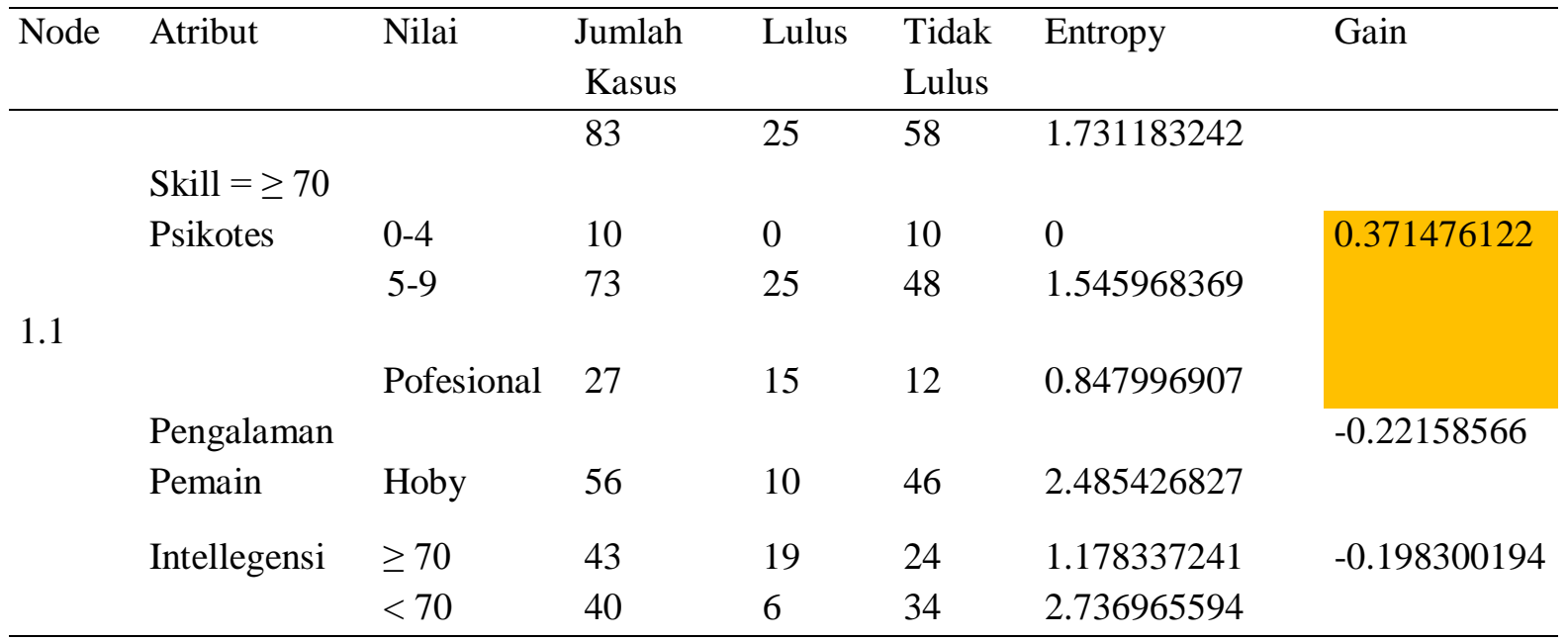

Based on the results of the above analysis, the psychological test attribute with a gain value is obtained the highest, which is equal to 0.371476122. Furthermore, the Psychotest attribute becomes a node 1.1 in the decision tree.

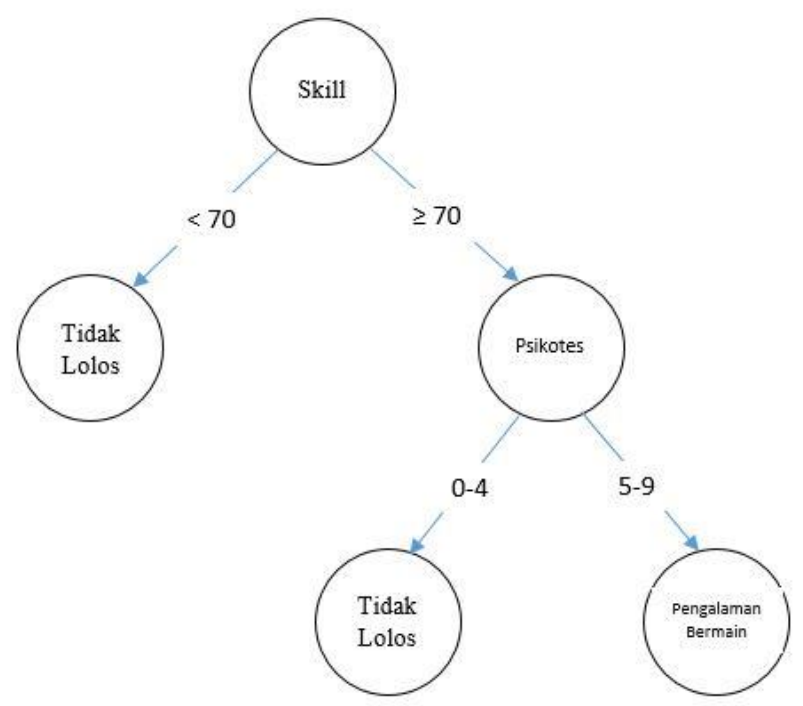

Figure 3. Decision Tree Result of Node Calculation 1.1 
Table 5. Node Calculation 1.2

\begin{tabular}{|c|c|c|c|c|c|c|c|}
\hline Node & Atribut & Nilai & $\begin{array}{r}\text { Jumlah } \\
\text { Kasus }\end{array}$ & Lulus & $\begin{array}{l}\text { Tidak } \\
\text { Lulus }\end{array}$ & Entropy & Gain \\
\hline \multirow{8}{*}{1.2} & Skill $=\geq 70$ & & & & & & \\
\hline & Psikotes $=5$ & & & & & & \\
\hline & & & 73 & 25 & 48 & 1.545968369 & \\
\hline & \multirow{3}{*}{$\begin{array}{l}\text { Pengalaman } \\
\text { Pemain }\end{array}$} & \multirow[t]{2}{*}{ Profesional } & \multirow[t]{2}{*}{27} & \multirow[t]{2}{*}{15} & \multirow[t]{2}{*}{12} & \multirow[t]{2}{*}{0.847996907} & \multirow{3}{*}{-0.155005249} \\
\hline & & & & & & & \\
\hline & & Hoby & 46 & 10 & 36 & 2.201633861 & \\
\hline & \multirow[t]{2}{*}{ Intellegensi } & $\geq 70$ & 43 & 19 & 24 & 1.178337241 & \multirow{2}{*}{-0.102337716} \\
\hline & & $<70$ & 30 & 6 & 34 & 2.321928095 & \\
\hline
\end{tabular}

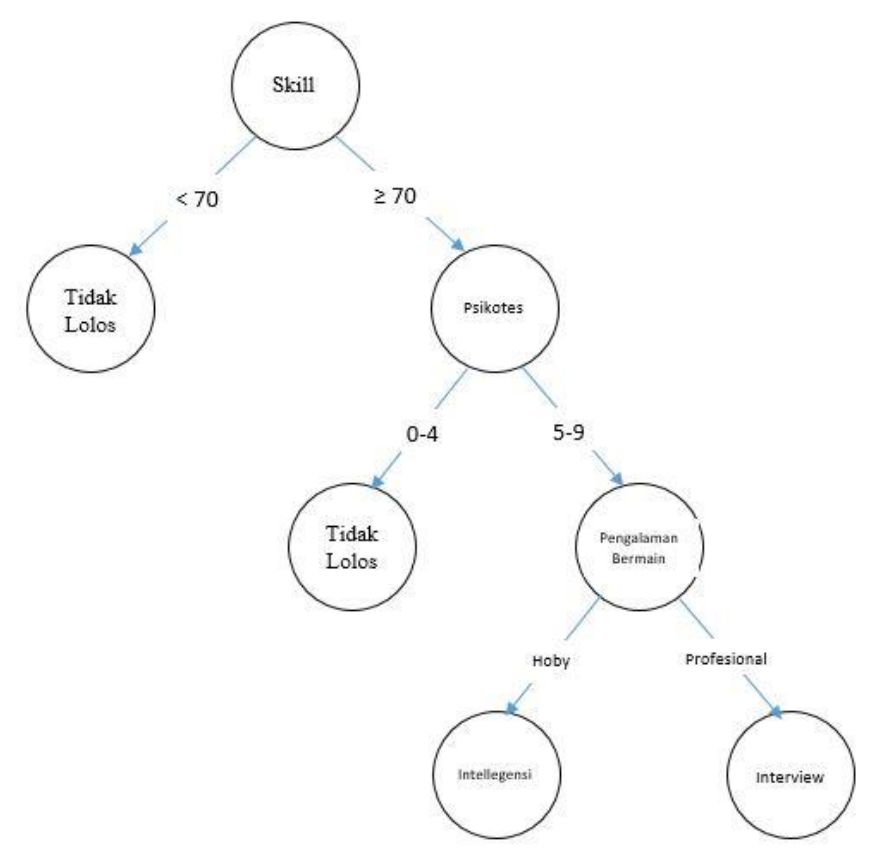

Figure 4. Decision Tree calculation result of node 1.2

Table 6. Node Calculation 1.3

\begin{tabular}{lllllll}
\hline Node Atribut & Nilai & $\begin{array}{l}\text { Jumlah } \\
\text { Kasus }\end{array}$ & Lulus & $\begin{array}{l}\text { Tidak } \\
\text { Lulus }\end{array}$ & Entropy & Gain \\
\hline
\end{tabular}

Skill $=\geq 70$

1.3 Psikotes $=5-9$

$\begin{array}{llll}30 & 6 & 24 & 2.3219281\end{array}$

Pengalaman

Pemain $=$

Profesional

Intellegensi

$\begin{array}{lllll}\geq 70 & 9 & 6 & 3 & 0.5849625 \\ <70 & 21 & 0 & 21 & 0\end{array}$

2.1464393 


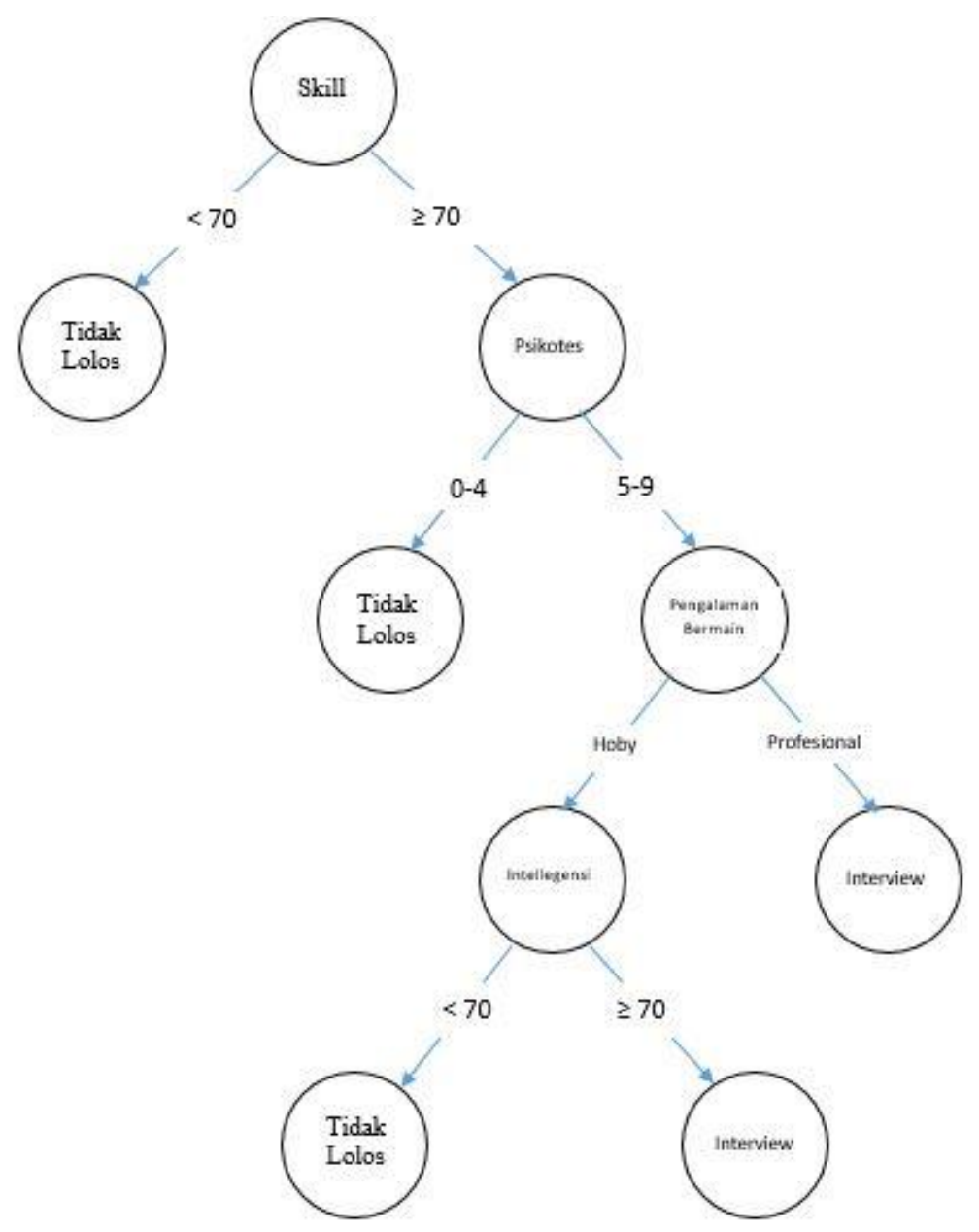

Figure 5. Decision Tree Result of node calculation 1.3

\section{A. Result}

From the decision tree, there are rules that will be used to determine the graduation of prospective e-sports team members, namely:

- $\quad$ IF Skill <70 THEN Doesn't Pass

- $\quad$ IF Skill $\geq 70^{\wedge}$ Psychological test $=0-4$ THEN Does not pass

- $\quad$ IF Skill $\geq 70^{\wedge}$ Psychological test $=5-9 \wedge$ Playing Experience $=$ Hobbies $\wedge$ Intelligence $<70$ THEN Did not pass

- $\quad$ IF Skill $\geq 70^{\wedge}$ Psychological test $=5-9 \wedge$ Playing Experience $=$ Hobbies ${ }^{\wedge}$ Intelligence $\geq 70$ THEN Passed

- $\quad$ IF Skill $\geq 70^{\wedge}$ Psychological test $=5-9 \wedge$ Playing Experience $=$ THEN Professional Passed

\section{B. Discussion}

The application of the C4.5 algorithm in the recruitment classification of E-sports team members is a system that can classify prospective members of the E-sports team whether they qualify as team members or not. The following are samples that qualify to become team members because they have scored criteria that have met the requirements specified in this system, these criteria are as follows: 
Table 7. Criteria for classification of candidates who qualify as team members

\begin{tabular}{cll}
\hline No & & \multicolumn{1}{c}{ Kriteria } \\
\hline 1 & Skill & $\geq 70$ \\
2 & Psikotes & $5-9$ \\
3 & Pengalaman & Profesional \\
& Pemain & \\
4 & Intellegensi & $\geq 70$
\end{tabular}

The following is a sample that does not qualify as a team member because it gets a criteria score that does not meet the requirements specified in this system, the criteria are as follows:

Table 8. Criteria for classifying candidates who do not qualify as team members

\begin{tabular}{clll}
\hline No & & Kriteria \\
\hline 1 & Skill & $<70$ & \\
2 & Psikotes & $0-4$ & \\
3 & Pengalaman & Hoby & \\
& Pemain & & \\
4 & Intellegensi & $<70$
\end{tabular}

\section{CONCLUSION}

Based on the results of implementation and testing, it can be concluded that:

1. This system can already assist in determining the classification of e-sports team members according to predetermined criteria.

2. This system can assist HR in managing data on e-sports team members so that the time required is more efficient.

3. The results obtained from this test are only as a tool for decision makers. The decision to pass will ultimately be determined by the decision maker as well.

\section{SUGGESTED}

The suggestions that can be given to develop this research are as follows:

1. Researchers can then add to the test sample or attributes used in the calculation of the C4.5 algorithm to obtain more varied results.

2. Research can be carried out by making comparisons with other algorithms to find a better level of accuracy in solving member recruitment or other recruitment problems.

3. System testing is a process that must be considered in order to obtain optimal results and in accordance with the objectives of a decision support system made. 


\section{REFERENCES}

[1] Arifin, M. F. (2018). Penerapan Algoritma Klasifikasi C4.5 dalam Rekomendasi Penerimaan Mitra Penjualan Studi Kasus : PT Atria Artha Persada. Incom Tech, 16.

[2] Buulolo, E. (2017). C4.5 Algorithm To Predict The Impavt Of The Earthquake. International Journal of Engineering Research \& Technology (IJERT), 7.

[3] Erwanto, F. (2019). Penerapan Algoritma C45 Untuk Penentuan Kelayakan Penerimaan Pegawai Di KEMENKUMHAM. Bina Darma Conference On Science 2019 (p. 8). Palembang: Universitas Bina Darma.

[4] Kurniawan, T. C. (2017). Penerapan Algoritma C4.5 Dalam Penerimaan Calon Karyawan PT. Telkom Akses Area Lampung Berbasis Website. SEMNAS IIB DARMAJAYA (p. 11). Bandar Lampung: SEMNAS IIB DARMAJAYA.

[5] Wahyuni, S. (2018). The Implementation Of Decision Tree Algorithm C4.5 Using Rapidminer In Analizing Dropout Students. 4th International Conference On Technical and Vocation Education and Training (p. 6). Padang: Researchgate. 